\title{
Deteksi Diarrhoegenic E. coli pada Sampel Feses Penderita Diare di Puskesmas Batulicin dan Pagatan Kabupaten Tanah Bumbu dengan Polymerase Chain Reaction (PCR)
}

\author{
Detection of Diarrhoegenic E. coli on Diarrhea Feces Samples at Batulicin and \\ Pagatan Communities Health Centre, Tanah Bumbu District with \\ Polymerase Chain Reaction (PCR)
}

\author{
Ika Setianingsih*, Dicky Andiarsa, Erli Hariyati \\ Balai Litbangkes Tanah Bumbu Kawasan Perkantoran Pemda Tanah Bumbu \\ Gunung Tinggi Kecamatan Batulicin, Tanah Bumbu, Indonesia \\ *Corresponding Author: ikasetianingsih59@gmail.com
}

Received: August 10, 2019; Revise: November 28, 2019; Accepted: December 2, 2019

DOI : https://doi.org/10.31001/biomedika.v12i2.597

\begin{abstract}
ABSTRAK
Diarrhoegenic E. coli (DEC) merupakan kelompok strain E. coli patogenik yang diketahui menjadi salah satu penyebab penyakit diare. Kasus diare masih cukup tinggi di negara-negara yang sedang berkembang seperti Indonesia. Di Kabupaten Tanah Bumbu Kalimantan Selatan khususnya di wilayah kerja Puskesmas Batulicin dan Pagatan memiliki angka kasus diare yang masih fluktuatif. Penelitian ini bertujuan mendeteksi DEC pada sampel feses penderita diare di wilayah kerja Puskesmas Batulicin dan Pagatan dengan pemeriksaan PCR. Desain penelitian Cross Sectional dengan jumlah sampel feses sebanyak 15, dikumpulkan selama 3 bulan (Agustus - Oktober 2018). Sampel feses diperiksa menggunakan PCR untuk mendeteksi keberadaan strain DEC yakni EAEC, ETEC, dan EPEC serta EHEC. Tiga dari lima belas (20\%) sampel diketahui positif DEC. Strain ETEC ditemukan pada 2 sampel (0,13\%), masing-masing dari Puskesmas Batulicin dan Puskesmas Pagatan, sedangkan strain EPEC dan EAEC ditemukan pada 1 sampel $(0,07 \%)$ yang sama dari Puskesmas Pagatan. Strain EHEC tidak terdeteksi di semua sampel. Strain Diarrhogenic E. coli yang ditemukan pada penelitian ini adalah EAEC, ETEC, dan EPEC. Namun demikian, belum dapat dipastikan bahwa ketiga strain DEC tersebut merupakan penyebab penyakit diare, perlu ada penelitian lebih lanjut. Masyarakat hendaknya dapat meningkatkan kesadaran akan pentingnya perilaku hidup bersih dan sehat terutama dalam mengkonsumsi makanan dan minuman, sehingga diharapkan mampu menekan angka kasus diare.

Kata kunci: Diarrhoegenic E. coli; Tanah Bumbu; Polymerase Chain Reaction (PCR); Diare
\end{abstract}

\begin{abstract}
Diarrhoegenic E. coli (DEC) is a group of pathogenic E. coli strains known to be one of the causes of diarrheal disease. Diarrhea cases are still quite high in developing countries like Indonesia. Tanah Bumbu Regency, especially Batulicin and Pagatan, have a fluctuating rate of diarrhea. This study aims to detect DEC in diarrheal patients in the work area of Batulicin and Pagatan Health Centers using the PCR examination method. Cross Sectional research design with a total sample of 15 respondents collected for 3 months (August - October 2019). Stool samples were examined using the PCR method to detect the presence of DEC strains namely EAEC, ETEC, and EPEC and EHEC. Three out of fifteen (20\%) samples were known to be positive for Diarrhoegenic E. coli (DEC). ETEC strains were found in 2 $(0,13 \%)$ sample, each from the Batulicin Health Center and the Pagatan Health Center, while EPEC and EAEC strains were found in the same 1 (0,07\%) sample from the Pagatan Health Center. EHEC strain was not detected in all samples. Diarrhogenic E. coli strains found in this study are EAEC, ETEC, and EPEC. However, it cannot be ascertained yet that the three strains are the cause of the diarrheal disease, it needs to be further to do comprehensive research. The community should be able to increase awareness of the importance of clean and healthy behavior, especially food and beverages consumption, so it can reduce the number of diarrhea cases.
\end{abstract}

Key word: Diarrhoegenic E. coli; Polymerase Chain Reaction (PCR); Tanah Bumbu; Diarrhoe 


\section{PENDAHULUAN}

Diare hingga saat ini masih menjadi salah satu penyebab utama kematian anak di bawah usia 5 tahun. Hampir lebih dari 9 juta anak meninggal setiap tahunnya disebabkan diare (Black, M \& Bryce, 2003). Diare sangat prevalen di negara-negara sedang berkembang, termasuk di Indonesia. Diare di Indonesia menduduki peringkat ke-7 sebagai penyebab kematian terbesar pada bayi prematur, dan peringkat ke-6 penyebab kematian di semua usia (Institute for Health Metrics and evaluation, 2017).

Diare merupakan penyakit menular yang terjadi secara fecal oral, yang penularannya dapat terjadi melalui vektor, air, tanah, tangan, maupun makanan yang terkontaminasi oleh agen penyebab diare itu sendiri. Oleh karenanya diare seringkali dikaitkan dengan rendahnya Perilaku Hidup Bersih dan Sehat (PHBS) serta buruknya sanitasi lingkungan. Faktor penyebab diare lainnya adalah keterbatasan akses air bersih dan angka kemiskinan yang mempengaruhi status gizi dan nutrisi (Gupta, 2014).

Penanganan diare yang mudah dengan biaya pengobatan yang masih sangat terjangkau, menyebabkan penyakit tersebut seringkali kurang mendapatkan perhatian. Angka kasus diare disejumlah wilayah di Kabupaten Tanah Bumbu Provinsi Kalimantan Selatan, seperti Puskesmas Pagatan dan Batulicin berdasarkan data dari Dinas Kesehatan setempat hingga saat inipun masih fluktuatif. Data kasus yang ada di Dinas Kesehatanpun belum mencakup data kasus di sejumlah fasilitas kesehatan lainnya, seperti rumah sakit maupun klinik. Pada penelitian sebelumnya menunjukkan bahwa Pagatan termasuk dalam wilayah berisiko diare (Andiarsa et al., 2018)

Salah satu mikroorganisme agen penyebab diare, sekaligus indikator biologis pencemaran lingkungan oleh feses yang paling umum diketahui adalah Escherichia coli. Escherichia coli sebenarnya merupakan flora normal dalam saluran pencernaan manusia. namun sejumlah strainnya diketahui dapat menyebabkan penyakit enterik yang disebut Diarrhoegenic E. coli (DEC). Strain DEC berdasarkan profil pathogenitasnya terdiri dari Enterohaemorrhagic E. coli (EHEC), Enteropathogenic E. coli (EPEC), Enteroinvasive (EIEC), dan Enterotoxigenic E. coli (ETEC), serta Diffusely Adherent E. coli (DAEC) (Clements, Young, Constantinou, \& Frankel, 2012). Sejumlah penelitian sebelumnya menyebutkan bahwa EAEC, ETEC, dan EPEC memiliki frekuensi yang cukup tinggi di sejumlah negara dibandingkan dengan strain DEC (Acosta et al., 2016).

Escherichia coli sangat mudah untuk di kultur di laboratorium, namun untuk melakukan identifikasi genotip patogeniknya membutuhkan metode deteksi gen virulensi seperti PCR yang kini mulai banyak dikembangkan. Penelitian terkait DEC belum pernah dilakukan di Kabupaten Tanah Bumbu.

Oleh karenanya pada penelitian ini ingin mendeteksi DEC yang umumnya ditemukan pada penderita diare di wilayah Puskesmas Pagatan dan Batulicin dengan menggunakan metode pemeriksaan molekuler atau Polymerase Chain Reaction (PCR). 


\section{METODE PENELITIAN}

Jenis penelitian ini deskriptif observasional dengan desain studi CrossSectional. Penelitian ini telah memperoleh persetujuan etik dari Komisi Etik Badan Penelitian dan Pengembangan Kesehatan, Kementerian Kesehatan RI dengan nomor LB.02.01/2/KE.228/2018.

\section{Alat dan Bahan}

Bahan yang dibutuhkan dalam penelitian ini diantaranya adalah media Air Peptone atau AP (Merck, Germany) sebagai media transport, media kultur bakteri yakni Mac-Conkey Agar atau MC (Merck, Germany), Eosyn Methyline Blue atau EMB (Oxoid, England) sedangkan bahan yang dibutuhkan untuk pemeriksaan PCR yakni DNA Extraction Kit (Vivantis, Malaysia), primer (Bioneer, Korea), PCR Master Mix (Vivantis, Malaysia), Ethidium Bromida $10 \mathrm{~mL}$, dan DNA Ladder, serta Blue Juice Gel Loading Buffer. Pada penelitian ini digunakan pula kontrol positif ETEC yang diperoleh dari Pusat Penelitian dan Pengembangan Biomedis Kesehatan Kementerian Kesehatan Jakarta.

Alat yang dibutuhkan yakni jarum ose (lokal), autoclave, tip (Axygen, China), microplate PCR tube 0,1 mL 96 well (Applied Biosystems, China), adhesive film (Applied Biosystems, China), dan crytube $1,5 \mathrm{~mL}$ (Thermo Fisher Scientific, USA), serta pot sampel feses (lokal).

\section{Prosedur Penelitian}

\section{Pengambilan Sampel Feses}

Sampel feses berhasil dikumpulkan dari 15 penderita pasien yang datang berobat ke Puskesmas Batulicin dan Pagatan, dari bulan Agustus hingga Oktober 2018. Pasien telah memenuhi kriteria inklusi dan eksklusi, yakni berusia kurang dari 64 tahun, berdomisili di wilayah tersebut, dan diare yang dialami disebabkan oleh bakteri berdasarkan hasil diagnosa, serta bersedia berpartisipasi dalam penelitian dengan menandatangani lembar persetujuan Inform Consent.

Pengambilan sampel dilakukan dengan koleksi feses segar yang kemudian dimasukkan dalam botol sampel steril berisi media transport AP yang telah steril pula. Botol sampel diberi label dengan keterangan nama pasien, usia, jenis kelamin, dan tanggal pengambilan sampel, serta petugas puskesmas yang melakukan pengambilan sampel.

\section{Kultur Bakteri}

Sampel yang telah diperoleh diupayakan untuk segera dikultur. Sampel feses kemudian dikultivasi pada media MC. Koloni yang diduga E. coli kemudian dipindahkan ke media selektif EMB dengan metode gores menggunakan ose. Koloni E. coli akan memberikan tampilan warna khas hijau metalik pada media EMB.

Kontrol positif yang digunakan merupakan isolat E. coli ETEC (ATCC 35401) yang diperoleh dari Pusat Penelitian dan Pengembangan Biomedis dan Teknologi Dasar Kesehatan, Badan Litbangkes, Kementerian Kesehatan RI.

\section{Ektraksi DNA Bakteri}

Koloni bakteri sebanyak 2-3 ose dimasukkan ke dalam tube berisi $100 \mu \mathrm{L}$ buffer R1 lalu diresuspensikan hingga tercampur rata, kemudian disentrifuse pada 10.000 x $\mathrm{g}$ selama 3 menit. Supernatan dibuang sehingga menyisakan pellet atau endapan yang ada. Pellet 
diresuspensi kembali dengan menambahkan $180 \mu \mathrm{L}$ buffer R2 dan 20 $\mu \mathrm{L}$ proteinase $\mathrm{K}$, kemudian di vortex agar tercampur rata lalu diinkubasi pada suhu $65{ }^{\circ} \mathrm{C}$ selama 20 menit dalam shaking waterbath. Buffer BG ditambahkan sebanyak $400 \mu \mathrm{L}$ dan divortex hingga homogen, kemudian diinkubasi pada suhu $65{ }^{\circ} \mathrm{C}$ selama 10 menit. Etanol absolute kemudian ditambahkan sebanyak $200 \mu \mathrm{L}$, lalu vortex kembali sehingga tercampur rata. Sampel kemudian dipindahkan ke dalam column tube, kemudian disentrifuse kembali pada $10.000 \mathrm{x}$ g selama 1 menit. Cairan yang turun dalam tube dibuang sehingga menyisakan lisat yang tertinggal pada filter column.

Apabila pada filter column masih menyisakan banyak cairan, sebanyak 200 $\mu \mathrm{L}$ buffer $\mathrm{BG}$ dapat ditambahkan dan sentrifuse kembali pada 10.000 x $\mathrm{g}$ selama 1 menit. Column dicuci dengan $650 \mu \mathrm{L}$ Wash Buffer yang telah diencerkan dengan $40 \mathrm{~mL}$ etanol absolut, kemudian disentrifuse pada $10.000 \mathrm{x} \mathrm{g}$ selama 1 menit, buang cairan hasil penyaringan untuk menghilangkan residu atau sisa etanol.

Menempatkan column pada microtube yang baru dan bersih. Tambahkan 50-100 $\mu \mathrm{L}$ elution buffer yang telah dihangatkan langsung pada membran column dan biarkan selama 2 menit. Kemudian sentrifuse pada $10.000 \mathrm{x}$ $\mathrm{g}$ selama 1 menit untuk menghasilkan DNA murni, kemudian ekstrak DNA yang diperoleh dapat disimpan terlebih dahulu sebelum digunakan pada suhu $4{ }^{\circ} \mathrm{C}$ atau $20{ }^{\circ} \mathrm{C}$.

\section{Amplifikasi menggunakan fragmen DNA spesifik}

Prosedur amplifikasi PCR fragmen DNA spesifik menggunakan oligonukleotida primer untuk mendeteksi gen virulensi dari strain DEC yakni EAEC ( $p C V D 432)$, ETEC (eltBl atau $l t)$, dan EPEC $(b f p A)$ serta EHEC (St1). Urutan basa-basa DNA primer atau sequen DNA primer ditunjukkan pada tabel 1. Amplifikasi PCR dilakukan dalam $50 \mu 1$ larutan reaksi yang mengandung 1 $\mu \mathrm{L}$, Taq M 12,5 $\mu \mathrm{L} ; \mathrm{MgCl} 1,5 \mu \mathrm{L}$; dan NFW $4 \mu \mathrm{L}$, serta volume sampel $5 \mu \mathrm{L}$. Reaksi amplifikasi adalah sebagai berikut, yakni satu kali siklus pada $94{ }^{\circ} \mathrm{C}$ selama 5 menit, diikuti dengan 40 kali siklus pada $94{ }^{\circ} \mathrm{C}$ selama 30 detik, $48{ }^{\circ} \mathrm{C}$ selama 30 detik, dan $72{ }^{\circ} \mathrm{C}$ selama 30 detik. Tahap akhir ditambahkan dengan satu kali siklus pada suhu $72{ }^{\circ} \mathrm{C}$ selama 5 menit. Produk PCR selanjutnya dielektroforesis dengan menggunakan 1,5\% agarosa dengan $1 \mathrm{X}$ TAE bufer, dilakukan pewarnaan dengan EtBr $\quad(50 \quad \mathrm{ng} / \mathrm{ml}), \quad$ kemudian divisualisasikan pada UV illuminator. Marker yang digunakan adalah 100 bp DNA ladder. Besaran unit pasangan basa pita DNA sampel yang nampak sesuai dengan ukuran unit pasangan basa primer yang digunakan menandai gen virulensi masing-masing strain DEC (Tabel 1).

\section{Analisis Data}

Data yang tersaji merupakan data nominal atau bersifat kualitatif yang kemudian dianalisis secara deskriptif. 
Tabel 1. Data Sequen Primer

\begin{tabular}{|c|c|c|c|c|}
\hline Strain & $\begin{array}{l}\text { Target } \\
\text { gen }\end{array}$ & Sequen Primer & $\begin{array}{l}\text { Ukuran } \\
\text { (bp) }\end{array}$ & Ref. \\
\hline EAEC & $p C V D 432$ & $\begin{array}{l}\text { CTGGCGAAAGACTGTATCAT } \\
\text { CAATGTATAGAAATCCGCTGTT }\end{array}$ & 630 & $\begin{array}{l}\text { (Schmidt et al., } \\
1995)\end{array}$ \\
\hline EHEC & St 1 & $\begin{array}{l}\text { AAACAGGTGAAACTGTTGCC } \\
\text { CTCTGCAGATTAACCCTCTGC }\end{array}$ & 454 & $\begin{array}{l}\text { (Sujaya et al., } \\
\text { 2010) }\end{array}$ \\
\hline EPEC & $b f p A$ & $\begin{array}{l}\text { AATGGTGCTTGCGCTTGCTGC } \\
\text { GCCGCTTTATCCAACCTGGTA }\end{array}$ & 326 & $\begin{array}{l}\text { (Gunzburg, } \\
\text { Tornieporth, \& } \\
\text { Riley, 1995) }\end{array}$ \\
\hline ETEC & eltBI (lt) & $\begin{array}{l}\text { CATAATGAGTACTTCGATAGAGGAAC } \\
\text { GAAACCTGCTAATCTGTAACCATCC }\end{array}$ & 402 & $\begin{array}{l}\text { (Nada, RA et al., } \\
\text { 2010) }\end{array}$ \\
\hline
\end{tabular}

\section{HASIL DAN PEMBAHASAN}

Total sampel feses yang diperoleh pada penelitian ini sebanyak 15 . Escherichia coli berhasil diisolasi dari seluruh sampel, 6 (40\%) dari Puskesmas Batulicin dan $9(60 \%)$ dari Puskesmas Pagatan. Penderita diare dari Puskesmas Batulicin yang bersedia menjadi responden berusia anak-anak $(50 \%)$ dan dewasa (50\%), sedangkan dari Puskesmas Pagatan adalah bayi dan balita (100\%).

Keberadaan E. coli pada seluruh sampel dalam penelitian ini menunjukkan bahwa E. coli sangat umum ditemukan pada feses, meskipun di sejumlah penelitian lain hanya menemukan 64\% (Ali et al., 2012) dan 59\% (Virpari, Nayak, Thaker, \& Brahmbhatt, 2013) dari jumlah sampel feses yang diperiksa. Perbedaan hasil pemeriksaan dapat dipengaruhi oleh perbedaan metode deteksi yang digunakan. Hal tersebut dibuktikan dari hasil penelitian yang membandingkan skrining isolat $E$. coli pada feses, diketahui bahwa E. coli terdeteksi sebanyak $91,5 \%$ sampel berdasarkan karakteristik koloni yang tumbuh pada media EMB, 76\% diantaranya positif setelah diuji biokimia, dan hanya $12,5 \%$ dengan uji Enzym Immunoassay (EIA) (Kabiru, Bello, Kabir, Grande, \& Morabito, 2015).
Bakteri yang ada pada feses sebagian besar merupakan flora normal dalam saluran pencernaan dan jenisnya sangatlah beragam, tidak hanya $E$. coli, namun juga bakteri lainnya seperti Lactobacillus sp, Eubacterium sp, maupun Clostridium sp, serta masih banyak lagi lainnya. Terdapat 400-500 jenis bakteri yang berbeda ditemukan pada usus manusia dewasa yang sehat, sebagian kecil diantaranya dapat dikultur dari sampel feses (Ramakrishna, 2007).

Escherichia coli sebagai flora normal dalam saluran pencernaan mamalia memiliki peranan penting, diantaranya dalam interaksi antar mikrobial salah satunya adalah modulasi imun sistem, selain berfungsi dalam sistem metabolik seperti produksi vitamin K (Gorback, 1996; Krogfelt, Cohen, \& Conway, 2004). E. coli yang bersifat komensal dianggap sebagai bagian dari sistem imun bawaan organisme multiseluler, yang mencegah koloni strain enteropatogenik pada saluran pencernaan (Hudault, Guignot, \& Servin, 2001).

Escherichia coli bukanlah satusatunya penyebab utama diare, terdapat sejumlah agen penyebab lainnya baik dari kelompok bakteri, virus maupun parasit. Gambaran epidemiologi masing-masing agen diare tersebut berbeda-beda di setiap 
wilayah atau negara. Rotavirus dan DEC disebagian negara lebih predominan ditemukan. Penelitian sebelumnya yang dilakukan di Burkina Faso Finlandia pada pasien diare anak menyebutkan bahwa rotavirus ditemukan 30\%, DEC 24\%, dan bakteri lain seperti Salmonella sp hanya 9\% (Bonkoungou et al., 2013). Begitupula penelitian yang dilakukan di Afrika Tengah yang merupakan negara dengan angka kemiskinan cukup tinggi, menemukan $47 \%$ rotavirus sebagai agen utama penyebab diare, sedangkan DEC hanya $9,7 \%$; sedangkan parasit seperti Entamomoeba histolytica dan Giardia labia sebesar 1\% (Breurec et al., 2016).

Hasil berbeda ditemukan di Baghdad Irak yang menyebutkan bahwa E. coli ditemukan 25,53\%, sedangkan rotavirus 17\% (Al-shuwaikh, Ibrahim, \& Shwaikh, 2015). Setiap penelitian memiliki tujuan dan fokus yang berbeda, sehingga hasil yang diperolehpun berbeda-beda. DEC merupakan salah satu agen diare yang paling mungkin ditemukan di lingkungan sekitar kita terutama di daerah dengan sanitasi dan tingkat higienis yang masih rendah, selain sumber penularannya yang mudah.

Penelitian DEC di Indonesia masih sangat sedikit, kemungkinan dikarenakan dampak yang ditimbulkan tidak signifikan, kepedulian masyarakat dan pihak-pihak terkait juga masih kurang, pemeriksaan rutinpun tidak dapat dilakukan di fasilitas kesehatan tingkat dasar yang umumnya lebih banyak melayani berbagai keluhan kesehatan masyarakat di tingkat pertama, dikarenakan pemeriksaan yang membutuhkan waktu, biaya, dan tenaga terlatih. Deteksi DEC sebenarnya dapat dilakukan dengan metode konvensional atau kultur di laboratorium, namun harus melalui pengujian biokimia yang membutuhkan waktu cukup panjang, begitupula dengan uji serologi. Metode yang saat ini banyak dikembangkan di banyak negara yakni PCR, namun metode ini membutuhkan bahan yang cukup mahal.

Penelitian terkait etiologi diare di Indonesia lebih banyak mengangkat cemaran E. coli pada sumber-sumber penularan. Padahal diketahui bahwa tidak semua E. coli bersifat patogen, hanya strain yang membawa faktor virulen yang dapat menyebabkan diare. Pada penelitian ini sampel dikumpulkan dari 2 puskesmas (Batulicin dan Pagatan) yang angka kasus diarenya cukup fluktuatif, dibandingkan puskesmas lainnya di Kabupaten Tanah Bumbu. Tiga dari lima belas (20\%) sampel diketahui positif Diarrhoegenic E. coli (DEC). Strain ETEC ditemukan pada $2(0,13 \%)$ sampel, masing-masing 1 sampel dari Puskesmas Batulicin (B1) dan 1 sampel dari Puskesmas Pagatan (P9), sedangkan strain EPEC dan EAEC ditemukan pada $1(0,07 \%)$ sampel yang sama dari Puskesmas Pagatan (P5). Hasil identifikasi tersebut diperoleh berdasarkan analisis pita DNA yang nampak pada pemeriksaan PCR. Strain EHEC tidak terdeteksi pada semua sampel.

Responden B1 berusia 7 tahun, berjenis kelamin perempuan, memiliki riwayat diare sebelumnya, dan tidak mengkonsumsi obat lainnya saat mengalami diare tersebut. Keluhan saat diare adalah perut terasa sakit dan mengalami demam serta batuk. Berdasarkan wawancara dengan ibunya, semua anggota keluarga memiliki kebiasaan minum air yang tidak diolah terlebih dahulu. Namun demikian, 
anggota keluarga lainnya tidak ada yang mengalami diare seperti yang sering dialami responden. Air yang dikonsumsi tersebut bersumber dari Perusahaan Daerah Air Minum (PDAM).

Gambar 1 berikut menunjukkan hasil visualisasi pita DNA sampel B1 yang diketahui memiliki panjang sequen sama dengan panjang sequen primer ETEC yakni 402 bp. Hal tersebut menunjukkan bahwa sampel B1 merupakan strain ETEC.

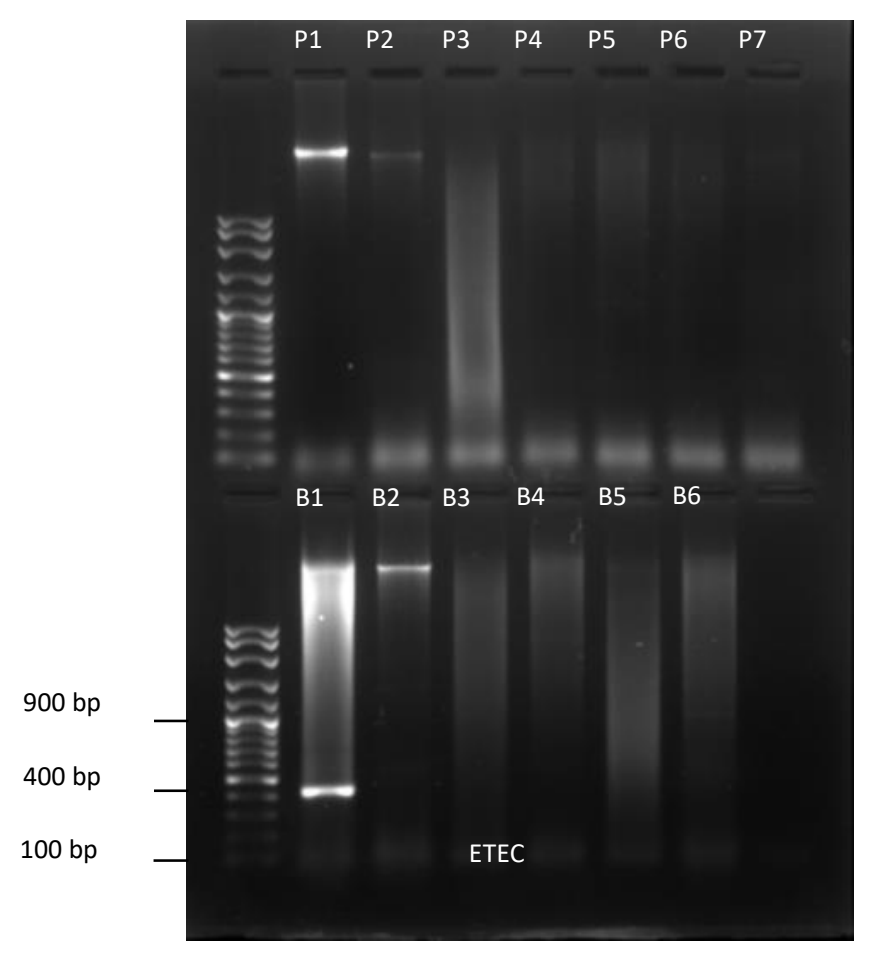

Gambar 1. Hasil analisis pita DNA pada sampel B1 positif ETEC

Wilayah kerja puskesmas Batulicin meliputi 7 desa dan 2 kelurahan. Tujuh puluh persen diantara wilayahnya merupakan daerah sungai atau rawa. Diare menjadi penyakit terbanyak ke-3 setelah ISPA dan hipertensi. Penderita diare tertinggi berada di Kelurahan Batulicin. Data profil kesehatan puskesmas tidak menampilkan kondisi PHBS maupun akses air bersih dari seluruh kelurahan, melainkan hanya sejumlah kecil kelurahan salah satunya Kersik Putih. Data menunjukkan bahwa kondisi PHBS dan akses air bersih di wilayah tersebut sudah cukup baik.
Namun demikian, 2 orang responden kami dalam penelitian ini tinggal di wilayah Kersik Putih, masing-masing berusia 7 tahun dan 36 tahun. Hal tersebut menunjukkan bahwa diare dapat terjadi pada berbagai rentang usia, tidak hanya bayi dan balita melainkan juga anak-anak hingga orang dewasa (Gurpreet, Tee, Amal, Paramesarvathy, \& Karuthan, 2011).

Sumber infeksi yang menyebabkan diare dapat diperoleh dari luar lingkungan keluarga, baik sekolah, tempat kerja, dan tempat-tempat umum lainnya, termasuk fasilitas layanan 
kesehatan. Sehingga diharapkan penerapan PHBS tidak hanya pada tatanan rumah tangga, melainkan juga pada tatanan-tatanan lainnya seperti yang diatur pada Permenkes RI No.2269/Menkes/per/XI/2011 tentang pedoman pembinaan Perilaku Hidup Bersih dan Sehat (Menteri Kesehatan RI, 2011).

Penelitian sebelumnya
menunjukkan bahwa PHBS dan
ketersediaan akses air bersih memiliki hubungan yang signifikan dengan angka kejadian diare (Irianty et al., 2018). Namun, pada penelitian lainnya menyebutkan sebaliknya bahwa tidak ada hubungan yang signifikan antara PHBS dengan kejadian diare. Terdapat 10 indikator PHBS yang menunjang peningkatan kesehatan keluarga, namun tidak semua indikator tersebut berhubungan signifikan terhadap kejadian diare di suatu wilayah meskipun demikian tetap menjadi faktor risiko yang perlu mendapatkan perhatian.

Pasien diare lainnya yang menjadi responden dari Puskesmas Batulicin tinggal di wilayah Batulicin. Kebiasaan tidak memasak air minum masih ditemukan pada salah satu rumah tangga responden. Air yang dikonsumsi bersumber dari PDAM yang kemudian ditampung dalam wadah dan langsung dikonsumsi. Diketahui bahwa air PDAM termasuk sumber air terlindung atau perpipaan, yang akan melalui beberapa tahap pengolahan sebelum akhirnya didistribusikan ke masyarakat, meskipun demikian tidak menutup kemungkinan kontaminasi tetap dapat terjadi.

Kontaminasi dari sumber air PDAM bisa terjadi dalam proses penyalurannya maupun penyimpanannya.
Hal tersebut dikuatkan oleh hasil penelitian tentang kualitas mikrobiologis air kobokan yang bersumber dari air PDAM dan sumur bor, diperoleh data bahwa $30 \%$ air PDAM dan $50 \%$ air sumur bor diketahui mengandung E. coli (Kusuma, et al. 2015). Penelitian lainnya juga menemukan bahwa masih banyak diantara penderita diare yang mengkonsumsi air sumur, PDAM, maupun air kemasan bahkan yang telah direbus (Sari, 2016).

Perilaku kebiasaan memasak air minum diketahui berpengaruh signifikan terhadap kejadian diare pada balita (Hairani \& Andiarsa, 2017). Mengolah air minum dengan cara dimasak pada suhu 65-100 ${ }^{\circ} \mathrm{C}$ selama kurang lebih 1 menit merupakan salah satu upaya untuk membunuh atau menginaktifkan mikroba patogen yang ada dalam air (World Gastroenterology Organisation, 2012).

Namun demikian, hasil penelitian sebelumnya pada anak balita usia 4-6 tahun yang menderita diare tidak menemukan hubungan yang signifikan antara kebiasaan memasak air dengan kualitas mikrobiologis air minum, begitupula kualitas mikrobiologis air minum dengan kejadian diare (Selviana, et al., 2017). Mikroba kontaminan tidak semuanya merupakan agen penyebab diare, dan masing-masing membutuhkan perlakuan yang berbeda hingga dapat menjadi inaktif atau mati.

Wilayah Batulicin memiliki kepadatan penduduk yang berbeda dengan Kersik Putih. Pemukiman yang ada di wilayah Batulicin lebih padat dikarenakan dekat dengan pusat kota atau perbelanjaan, selain itu juga dekat dengan laut yang memisahkan antara Kabupaten Tanah Bumbu dan Kotabaru. Kondisi 
lingkungan dan kebiasaan masyarakat di suatu wilayah menjadi salah satu faktor yang mempengaruhi perilaku sehat masyarakat setempat (Diouf, Tabatabai, Rudolph, \& Marx, 2014), seperti halnya kebiasaan buang air besar di laut maupun sungai yang masih ditemukan di wilayah tersebut. Hal tersebut meningkatkan risiko penyebaran penyakit diare.
Selain sampel B1, sampel P9 yang merupakan pasien diare dari puskesmas Pagatan diketahui pula merupakan strain ETEC. Responden berjenis kelamin perempuan berusia 1,5 tahun, tanpa riwayat penyakit diare sebelumnya dan tidak ada anggota keluarga yang sedang mengalami diare. Hasil visualisasi pita DNA sampel P9 ditunjukkan pada Gambar 2.

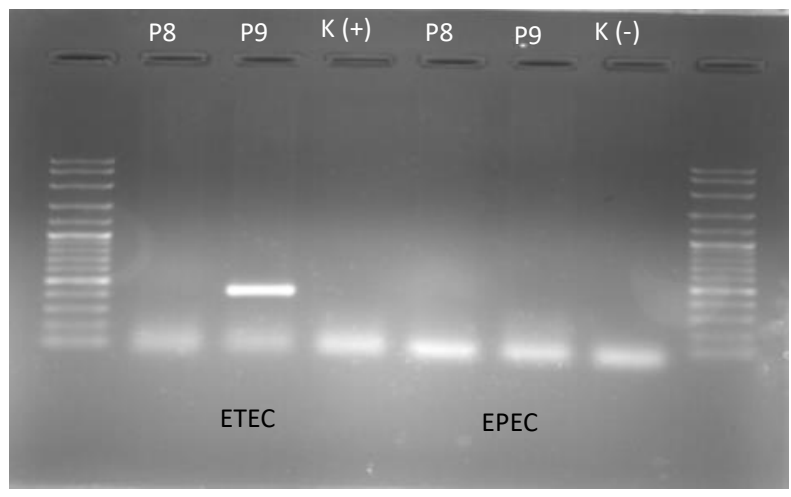

Gambar 2. Hasil analisis pita DNA pada sampel P9 positif ETEC

Gambar 1 dan 2 menunjukkan hasil elektroforesis tersebut tidak nampak pita DNA kontrol positif ETEC, meskipun pada sampel menunjukkan hasil yang positif. Hal tersebut kemungkinan disebabkan kontaminasi pada kultur isolat kontrol, karena setelah dilakukan pengujian ulang terhadap kontrol positif diperoleh hasil yang sesuai (Gambar $3)$.

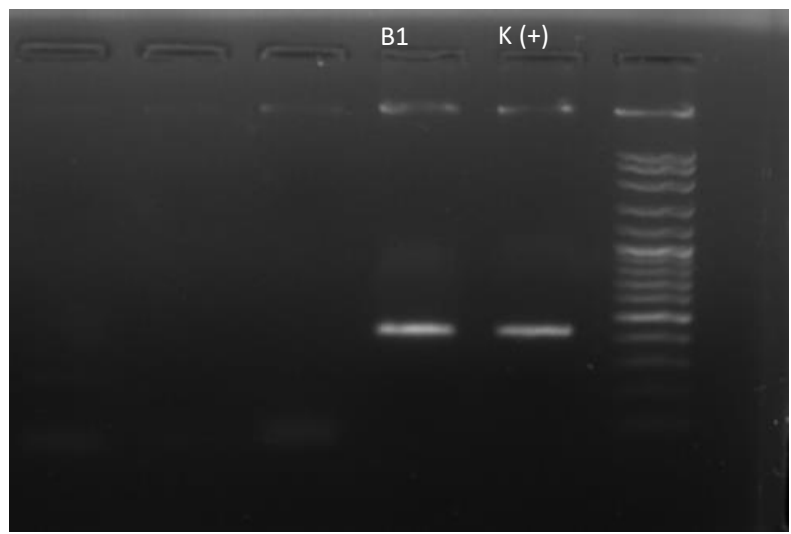

Gambar 3. Hasil analisis ulang pita DNA dari kontrol positif dan sampel B1 ETEC

Sampel positif lainnya merupakan responden dari Puskesmas Pagatan yakni P5, merupakan bayi berusia 8 bulan, belum pernah mengalami diare sebelumnya dan tidak ada anggota keluarga lainnya yang diare sebelum maupun pada saat itu. Gambar 4 menunjukkan hasil elektroforesis DNA dari sejumlah sampel. Terdapat beberapa pita DNA yang nampak, namun hanya 
pita DNA sampel P5 yang menunjukkan ukuran sequen DNA yang sesuai dengan ukuran sequen DNA primer EAEC yakni
630 bp. Hasil tersebut mengidentifikasi strain EAEC pada sampel P5.

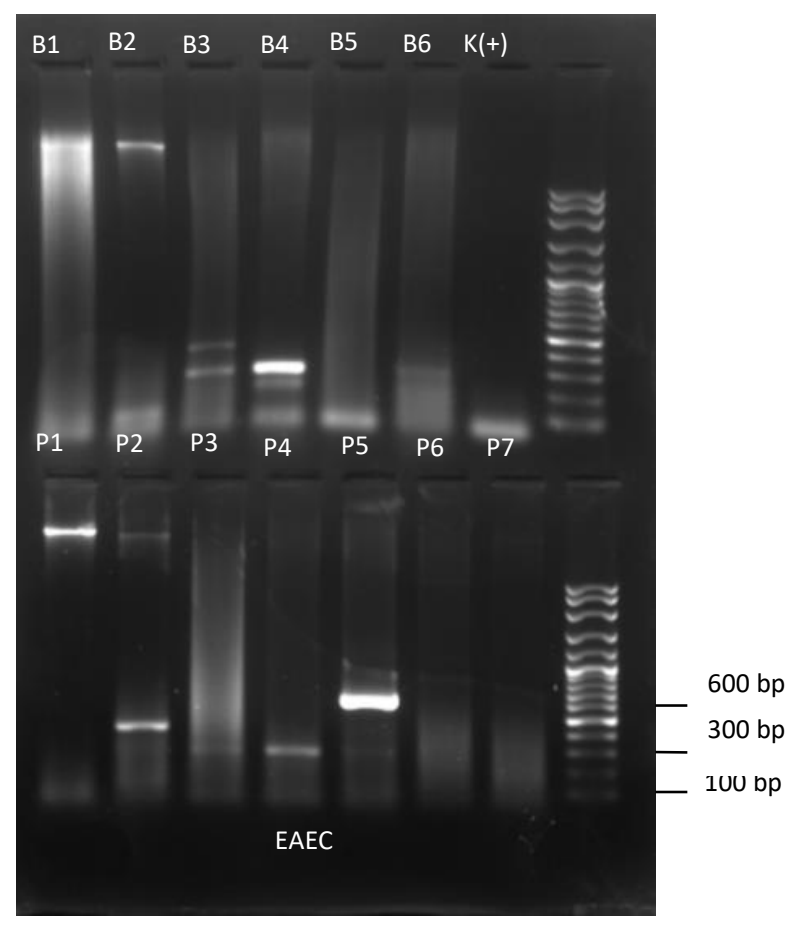

Gambar 4. Hasil analisis pita DNA pada sampel P5 positif EAEC

Pada analisis pita DNA, seringkali pada satu sampel nampak pita DNA berukuran berbeda dengan ukuran sequen DNA primer, seperti pada Gambar 4. Pita DNA tersebut merupakan pita DNA kontaminan yang kemungkinan diperoleh pada saat ekstraksi DNA sampel.

Hasil yang berbeda pada sampel yang sama (P5) ditunjukkan pada hasil visualisasi pita DNA dengan menggunakan primer EPEC (Gambar 5). Pita DNA muncul pada sampel B2 dan P5, namun hanya P5 yang menunjukkan ukuran sequen DNA yang sama dengan ukuran sequen DNA primer EPEC yaitu 326 bp. Hasil tersebut menunjukkan bahwa dalam satu sampel sangat mungkin dapat mengandung lebih dari satu strain DEC.
Wilayah kerja Puskesmas Perawatan Pagatan terdiri dari 27 desa dan 1 kelurahan, dengan kondisi daerah $55 \%$ diantaranya merupakan rancah atau rawa. Diare menjadi penyakit terbanyak ke-5 di wilayah tersebut, dengan jumlah penderita tertinggi di Kota Pagatan berdasarkan profil Puskesmas tahun 2017. Persentase rumah tangga ber-PHBS di wilayah Puskesmas Pagatan menurun $7,3 \%$ dari tahun-tahun sebelumnya, begitupula akses air minum berkualitas sebesar 29\%. Namun demikian persentase rumah sehat cukup tinggi yakni $45 \%$ (Redaksi, 2017a) 


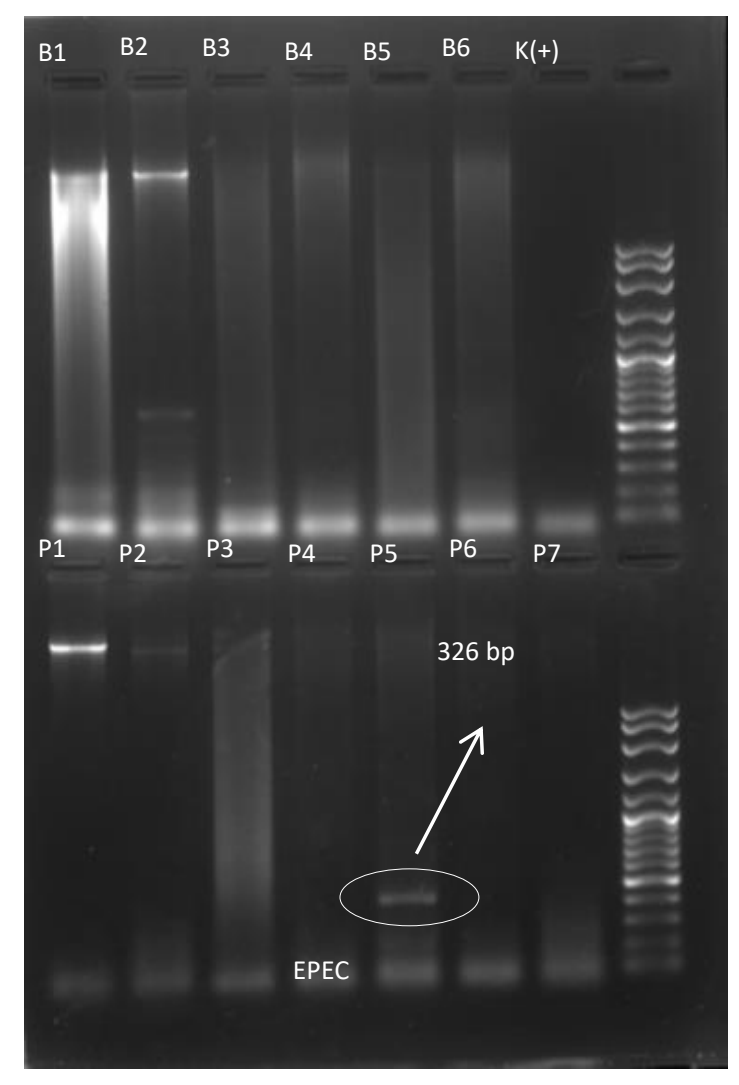

Gambar 5. Hasil analisis pita DNA pada sampel P5 positif EPEC

\begin{abstract}
Kasus diare yang ditemui terutama di Puskesmas Perawatan Pagatan umumnya adalah bayi dan balita, yang sebelumnya tidak memiliki riwayat anggota keluarga yang mengalami diare. Sebuah studi menyebutkan bahwa umumnya sebagian besar diare terjadi pada 2 tahun pertama kehidupan. Pada 2 tahun pertama kehidupan, seorang anak mulai mendapatkan makanan tambahan selain
\end{abstract} ASI dan terjadi proses pematangan sistem imun tubuh melalui berbagai aktivitas yang seringkali terjadi melalui kontak fisik dengan lingkungan sekitar (Praveen, Jordan, Priami, \& Morine, 2015). Pada kategori usia tersebut daya tahan tubuh atau sistem imunitas memang belum terbentuk secara baik, terutama bayi dan balita yang sejak lahir tidak mendapatkan ASI eksklusif (Diniz \& Figueiredo, 2014).

Air Susu Ibu (ASI) memberikan daya tahan tubuh terhadap penyakit infeksi secara alamiah, namun pada penelitian ini tidak dilakukan wawancara mengenai riwayat pemberian ASI pada penderita diare. Data dari Puskesmas Batulicin menunjukkan rendahnya persentase cakupan pemberian ASI eksklusif pada bayi (Redaksi, 2017b).

Hasil penelitian Azaria et al. (2017) menemukan hubungan antara pemberian asi eksklusif dengan kejadian diare (Azaria \& Rayhana, 2016). Hasil tersebut mendukung hasil penelitian sebelumnya yang menemukan hubungan pemberian asi eksklusif dengan angka diare akut pada bayi usia 0-1 tahun di Puskesmas Kuranji Kota 
Padang.(Rahmadhani, Lubis, \& Edison, 2013).

Perilaku hidup bersih dan sehat ibu juga berpengaruh terhadap kejadian diare pada anak, terutama perilaku mencuci tangan sebelum memberi makan dan setelah menceboki bayi. Hasil analisis DNA terhadap sampel yang diperiksa menunjukkan kesesuaian dengan hasil penelitian sebelumnya. Penelitian yang dilakukan di Cina menunjukkan bahwa DEC pada penderita diare hanya ditemukan sebesar 7,9\%; strain EPEC paling umum ditemukan sebesar 50\% (Zhou et al., 2018). Begitupula pada penelitian di India, diketahui bahwa prevalensi DEC yakni sebesar 11,8\%; EAEC ditemukan $5,7 \%$ diikuti ETEC 4,2\% dan EPEC 1,8\% (Dutta et al., 2013). Hal tersebut menunjukkan bahwa prevalensi penyakit diare yang disebabkan oleh DEC disejumlah wilayah sangat bervariasi, seperti halnya prevalensi DEC di Lima Peru diketahui sebesar 43\%, diantaranya strain EAEC 20,4\%; EPEC 14,2\% dan DAEC $11 \%$ (Acosta et al., 2016), begitupula prevalensi DEC di Kenya sebesar 55,9\% dengan EAEC merupakan strain yang paling sering ditemukan yakni $45 \%$, sedangkan EPEC, ETEC, dan EIEC berturut-turut sebesar 16,7\%; 16,3\% dan 8,2\% (Iijima et al., 2017).

Perbedaan distribusi DEC sangat dipengaruhi oleh kondisi geografis wilayah, termasuk iklim dan kondisi sosio demografis masyarakat setempat (Zhou et al., 2018), meskipun pada hasil penelitian Dutta menyebutkan bahwa diare yang disebabkan oleh DEC tidak spesifik pada musim-musim tertentu di sepanjang tahun (Dutta et al., 2013). Selain itu, metode pengambilan dan pemeriksaan sampelnya berbeda-beda. Pada penelitian Acosta maupun Iijima, desain studi yang digunakan masingmasing adalah kohort dan case-control dengan menggunakan metode pemeriksaan multiplex real-time $\mathrm{PCR}$ dan primer yang digunakan mendeteksi lebih dari 2 gen virulen untuk masingmasing strainnya. Hal tersebut meningkatkan sensitifitas dan spesifitas dalam mendeteksi gen virulen yang dimiliki oleh DEC. Semakin banyak primer yang digunakan untuk mendeteksi sejumlah gen virulen, maka semakin besar kemungkinan ditemukannya DEC.

Responden yang menjadi subjek penelitian juga memberikan pengaruh yang berbeda terhadap hasil, seperti halnya pada kelompok bayi dan balita yang memiliki multiple enteropatogen sebagai penyebab diare, tidak hanya DEC, namun masih banyak agen penyebab diare lainnya seperti rotavirus ataupun protozoa misalnya kelompok Entamoeba sp atau Giardia lambia.(Taniuchi, Sobuz, Begum, PlattsMills, et al., 2013) Meskipun pada penelitian lain menyebutkan lebih spesifik, bahwa pada kelompok usia 1 tahun rotavirus atau E. coli ditemukan lebih dominan kasusnya.

Begitupula pada kelompok subjek yang dibedakan berdasarkan tipe klinis diare yang dideritanya, menurut WHO terbagi menjadi diare akut dan persisten. Masing-masing memiliki gambaran epidemiologi yang berbeda. Penelitian lain menyebutkan bahwa diare akut pada umumnya diderita oleh orang dewasa berusia 20-29 tahun. (Gurpreet et al., 2011) 
Pada penelitian ini diketahui bahwa strain DEC yang ditemukan adalah ETEC, EPEC, dan EAEC. Hasil tersebut didukung oleh hasil penelitian sebelumnya yang menyebutkan bahwa strain DEC yang umum ditemukan menginfeksi adalah EAEC, ETEC, dan EPEC, berbeda halnya dengan EHEC, EIEC, dan DAEC yang sangat jarang bahkan seringkali tidak ditemukan di negara-negara sedang berkembang (Pouladfar et al., 2017). Namun demikian, pada penelitian lainnya, seperti di Costa Rica menemukan EIEC sebesar 15\% (Corrales \& Sandí, 2019), begitupula di Nigeria pada feses penderita diare anak usia 11-15 tahun sebesar 20\% (Abimiku, Ngwai, Nkene, \& Tatfeng, 2016), sedangkan DAEC ditemukan 18, 3\% dari sampel feses penderita diare akut pada anak di Brazil (Spano et al., 2017). Hal tersebut menunjukkan sebaran DEC yang bervariasi pada pasien diare.

Pada penelitian ini ditemukan pula mix dua strain DEC yakni EAEC dan EPEC pada 1 sampel dari Puskesmas Pagatan. Mix 2 atau lebih strain DEC dalam 1 sampel juga ditemukan pada penelitian Iijima dan prevalensi mix antara EAEC dengan EPEC diketahui paling banyak ditemukan (Iijima et al., 2017). Ketiga strain tersebut sangat umum ditemukan menyebabkan diare pada bayi dan balita. Namun tidak menutup kemungkinan bahwa tidak ditemukan strain lainnya dikarenakan primer yang digunakan kurang spesifik mendeteksi strain DEC lainnya. Namun demikian, primer yang digunakan pada penelitian ini merupakan primer yang umum digunakan pada sejumlah penelitian terdahulu.
Diarrhoegenic E. coli yang berhasil terdeteksi pada sampel feses penderita diare belum dapat membuktikan bahwa DEC merupakan penyebab diare. Pemeriksaan air rumah tangga dan air minum yang dikonsumsi perlu dilakukan pula untuk mengetahui ada tidaknya hubungan cemaran DEC pada air yang dikonsumsi dengan kejadian diare yang dialami penderita. Hal tersebut dibuktikan juga dari sejumlah penelitian yang menunjukkan DEC ditemukan $51,1 \%$ pada kelompok kontrol (non-diare) di Surabaya (Osawa et al., 2013), atau pada penelitian lainnya di Peru sebesar 42,6\% (Acosta et al., 2016). Penelitian menarik lainnya di Banglades juga menemukan bahwa sejumlah enteropatogen telah terdeteksi dari bulan pertama kehidupan, termasuk didalamnya E. coli, rotavirus, dan Entamoeba histolytica, meskipun kemudian dari analisis datanya menunjukkan terdapat hubungan yang signifikan dengan kejadian diare (Taniuchi, Sobuz, Begum, Platts-mills, et al., 2013).

Penelitian selanjutkan diharapkan dapat dilakukan secara komprehensif untuk mengetahui gambaran epidemiologi penyakit diare, memastikan etiologi penyakit dengan menemukan sumber pencemaran utama baik itu air, makanan, vektor, media lingkungan sekitar seperti tanah, maupun tangan. Metode pemeriksaannyapun diharapkan jauh lebih baik, tidak hanya bersifat kualitatif PCR namun juga kuantitatif seperti real-time PCR, dengan menggunakan sejumlah primer yang mampu mendeteksi beragam gen virulensi DEC dan lebih spesifik. 


\section{KESIMPULAN}

Strain Diarrhogenic E. coli yang ditemukan pada sampel feses penderita diare yang sebagian besar merupakan bayi dan balita di wilayah Puskesmas Batulicin dan Pagatan adalah EAEC, ETEC, dan EPEC. Masyarakat hendaknya dapat meningkatkan kesadaran akan pentingnya perilaku hidup bersih dan sehat terutama dalam mengkonsumsi makanan dan minuman, sehingga diharapkan secara tidak langsung mampu menekan angka kasus diare.

\section{UCAPAN TERIMA KASIH}

Ucapan terima kasih kami sampaikan kepada semua pihak yang telah mendukung kegiatan penelitian ini berlangsung, terutama dari dinas terkait yakni Kesbangpolinmas dan Dinas Kesehatan setempat, serta pimpinan dan pemegang program diare dari Puskesmas Batulicin maupun Pagatan. Terima kasih tak lupa pula kami sampaikan kepada Bapak Anorital, SKM., M.Kes. atas bimbingannya selama pelaksanaan penelitian hingga artikel ini disusun.

\section{DAFTAR PUSTAKA}

Abimiku, R. ., Ngwai, Y. ., Nkene, I. ., \& Tatfeng, Y. 2016. Molecular detection of diarrheagenic pathotypes of Escherichia coli from diarrheic patients in Keffi, Nigeria. Journal of Microbiology and Biomedical Research, 2(December 2017), 0-6. Retrieved from www.microbiozjournals.com

Acosta, G. J., Vigo, N. I., Durand, D., Riveros, M., Arango, S., Zambruni, M., \& Ochoa, T. J. 2016. Diarrheagenic Escherichia coli : Prevalence and pathotype distribution in children from Peruvian rural communities. Am J Trop Med Hyg, 95(3), 574-579. https://doi.org/10.4269/ajtmh.16-0220
Al-shuwaikh, A. M., Ibrahim, I. A. J., \& Shwaikh, R. M. A.-. 2015. Detection of E . coli and Rotavirus in Diarrhea among Children Under Five Years Old. Iraqi Journal of Biotechnology, 14(August), 8592. Retrieved from ttps://www.researchgate.net/publication/28 0741224

Ali, M. M. M., Mohamed, Z. K., Klena, J. D., Ahmed, S. F., Moussa, T. A. A., \& Ghenghesh, K. S. 2012. Molecular characterization of Diarrheagenic Escherichia coli from Libya. American Journal of Tropical Medicine and Hygiene, $86(5)$, 866-871. https://doi.org/10.4269/ajtmh.2012.110330

Andiarsa, D., Setyaningtyas, D. ., Hidayat, S., Setianingsih, I., Hamsyah, \& Hariyati, E. 2018. Spatial effect of refilling drinking water depots toward diarrhea in Pagatan, Subdistrict of Kusan Hilir, Tanah Bumbu District, Sounth Kalimantan. The 4th International Conference on Public Health, 4, 40-48. https://doi.org/10.17501/24246735.2018.4 105

Azaria, C., \& Rayhana. 2016. Hubungan penerapan perilaku hidup bersih dan sehat ( PHBS) ibu dengan kejadian diare balita di wilayah kerja Puskesmas Kacang Pedang 2015. Kedokteran Dan Kesehatan, 12(1). Retrieved from https://jurnal.umj.ac.id/index.php/JKK/arti cle/view/1551

Black, R. E., Morris, S. S., \& Bryce, J. 2003. Where and why are 10 million children dying every year? Lancet, 361(9376), 2226-2234. https://doi.org/10.1016/S01406736(03)13779-8

Bonkoungou, I. J. O., Haukka, K., Österblad, M., Hakanen, A. J., Traoré, A. S., Barro, N., \& Siitonen, A. 2013. Bacterial and viral etiology of childhood diarrhea in Ouagadougou , Burkina Faso. BioMed Central, 13(36), 2-7. Retrieved from http://www.biomedcentral.com/14712431/13/36

Breurec, S., Vanel, N., Bata, P., Farra, A., Nguyen, B. L., Onambélé, M., Rafa, C., \& Razakandrainibe, R. 2016. Etiology and Epidemiology of Diarrhea in Hospitalized Children from Low Income Country: A Matched Case-Control Study in Central African Republic. (December 2011), 1-18. https://doi.org/10.1371/journal.pntd.00042 83 
Clements, A., Young, J. C., Constantinou, N., \& Frankel, G. 2012. Infection strategies of enteric pathogenic Escherichia coli. Gut Microbes, 3(2), 71-87. https://doi.org/10.4161/gmic.19182

Corrales, C. P., \& Sandí, K. L. 2019. Diarrheagenic Escherichia coli in Costa Rican children: a 9 - year retrospective study. BMC Research Notes, (December 2016), $1-6$. https://doi.org/10.1186/s13104-019-4313-1

Diniz, L. M. O., \& Figueiredo, B. de C. G. e. 2014. The newborn's immune system. Revista Médica de Minas Gerais, 24(2), 227-233. https://doi.org/10.5935/22383182.20140056

Diouf, K., Tabatabai, P., Rudolph, J., \& Marx, M. 2014. Diarrhoea prevalence in children under five years of age in rural Burundi: An assessment of social and behavioural factors at the household level. Global Health Action, 7(1), 1-9. https://doi.org/10.3402/gha.v7.24895

Dutta, S., Guin, S., Ghosh, S., Pazhani, G. P., Rajendran, K., Bhattacharya, M. K., Takeda, Y., Nair, G. B., \& Ramamurthy, T. 2013. Trends in the prevalence of Diarrheagenic Escherichia coli among hospitalized diarrheal patients in Kolkata, India. $\quad P L O S \quad O N E, \quad 8(2)$. https://doi.org/10.1371/journal.pone.00560 68

Gorback, S. L. 1996. Medical Microbiology 4th edition (Fourth; Galveston, Ed.). Retrieved from

https://www.ncbi.nlm.nih.gov/books/NBK $7670 /$

Gunzburg, S. T., Tornieporth, N. G., \& Riley, L. E. E. W. 1995. Identification of Enteropathogenic Escherichia coli by PCRBased Detection of the Bundle-Forming Pilus Gene. Journal of Clinical Microbiology, 33(5), 1375-1377. Retrieved from https://www.ncbi.nlm.nih.gov/pubmed/761 5759

Gupta, A. 2014. Study of the prevalence of Diarrhoea in children under the age of five years: it's association with wasting. Indian Journal Sciences Research, 7(1), 13151318. Retrieved from http://citeseerx.ist.psu.edu/messages/downl oadsexceeded.html

Gurpreet, K., Tee, G. H., Amal, N. M., Paramesarvathy, R., \& Karuthan, C. 2011. Incidence and determinants of acute diarrhoea in Malaysia: a population-based study. Journal of Health, Population, and Nutrition, 29(2), 103-112. Retrieved from http://www.ncbi.nlm.nih.gov/pubmed/2160 8419\%0Ahttp://www.pubmedcentral.nih.g ov/articlerender.fcgi?artid=PMC3126982

Hairani, B., \& Andiarsa, D. 2017. Hubungan pengetahuan ibu dan perilaku memasak air minum dengan kejadian diare balita di Puskesmas Baringin Kabupaten Tapin tahun 2014. 3(1), 10-14. https://doi.org/10.22435/jhecds.v3il.5655

Hudault, S., Guignot, J., \& Servin, A. L. 2001. Escherichia coli strains colonising the gastrointestinal tract protect germfree mice against Salmonella typhimurium infection. Gut, $\quad 49(1), \quad 47-55$. https://doi.org/10.1136/gut.49.1.47

Iijima, Y., Oundo, J. O., Hibino, T., Saidi, S. M., Hinenoya, A., Osawa, K., Shirakawa, T., Osawa, R., \& Yamasaki, S. 2017. High prevalence of diarrheagenic Escherichia coli among children with diarrhea in Kenya. Japanese Journal of Infectious Diseases, 70(1), 80-83. https://doi.org/10.7883/yoken.JJID.2016.0 64

Institute for Health Metrics and evaluation. 2017. Global Burden of Diseases. Retrieved from http://www.healthdata.org/indonesia

Irianty, H., Hayati, R., \& Riza, Y. 2018. Hubungan Perilaku Hidup Bersih dan Sehat (PHBS) dengan kejadian diare pada balita. PROMOTIF: Jurnal Kesehatan Masyarakat, $\quad 8(1), \quad 1$. https://doi.org/10.31934/promotif.v8i1.224

Kabiru, L. M., Bello, M., Kabir, J., Grande, L., \& Morabito, S. 2015. Detection of pathogenic Escherichia coli in samples collected at an abattoir in Zaria, Nigeria and at different points in the surrounding environment. International Journal of Environmental Research and Public Health, 12(1), 679691. https://doi.org/10.3390/ijerph120100679

Krogfelt, K. A., Cohen, P. S., \& Conway, T. 2004. The Life of Commensal Escherichia coli in the Mammalian Intestine. EcoSal Plus, 1(1). https://doi.org/10.1128/ecosalplus.8.3.1.2

Kusuma, E. A., Rasyid, R., \& Endrinaldi. 2015. Identifikasi bakteri coliform pada air kobokan di rumah makan Kelurahan Andalas Kecamatan Padang Timur. Jurnal Kesehatan Andalas, 4(3), 845-849. Retrieved from 
http://jurnal.fk.unand.ac.id/index.php/jka/a rticle/view/374

Menteri Kesehatan RI. 2011. Peraturan Menteri Kesehatan No.2406 Tahun 2011 tentang Pedoman Umum Penggunaan Antibiotik. Peraturan Menteri Kesehatan No. 2406 TAHUN 2011 Tentang Pedoman Umum Penggunaan Antibiotik, 4. https://doi.org/10.1017/CBO97811074153 24.004

Nada, RA. Shaheen, HI. Touni , I., Fahmy, D., Armstrong, AW., Weiner, M., Klena, J. 2010. Design and validation of a multiplex polymerase chain reaction for the identification of Enterotoxigenic Escherichia coli and associated colonization factor antigens. Diagnostic Microbiology and Infectious Disease, 67(2), 134-142. https://doi.org/10.1016/j.diagnicrobio.2010 .01 .011

Osawa, K., Raharjo, D., Wasito, E. B., Harijono, S., Shigemura, K., Osawa, R., Sudarmo, S. M., Iijima, Y., \& Shirakawa, T. 2013. Frequency of diarrheagenic Escherichia coli among children in Surabaya, Indonesia. Japanese Journal of Infectious Diseases, 66(5), 446-448. https://doi.org/10.7883/yoken.66.446

Pouladfar, G., Arasteh-Far, A., Amin-Shahidi, M., Firoozian, N., Pourabbas, B., Moghadami, M., \& Fani, F. 2017. Characterization of Diarrheagenic E. coli causing a diarrheal outbreak in the south of Iran, Summer 2015. Asian Pacific Journal of Tropical Disease, 7(8), 491-495. https://doi.org/10.12980/apjtd.7.2017d7-94

Praveen, P., Jordan, F., Priami, C., \& Morine, M. J. 2015. The role of breast-feeding in infant immune system: a systems perspective on the intestinal microbiome. Microbiome, 3 (May 2016), 41. https://doi.org/10.1186/s40168-015-0104-7

Rahmadhani, E. P., Lubis, G., \& Edison. 2013. Hubungan pemberian ASI eksklusif dengan angka kejadian diare akut pada bayi usia 0-1 tahun di Puskesmas Kuranji, Kota Padang. Jurnal Kesehatan ..., 2(2), 62-66. Retrieved from http://jurnal.fk.unand.ac.id/index.php/jka/a rticle/view/121

Ramakrishna, B. S. 2007. The normal bacterial flora of the human intestine and its regulation. Journal of Clinical Gastroenterology, 41(SUPPL. 1), 2-6. https://doi.org/10.1097/MCG.0b013e31802 fba68

Redaksi, T. 2017a. Data Profil Puskesmas Pagatan 2017. Pagatan, Tanah Bumbu, Kalimantan Selatan.

Redaksi, T. 2017b. Profil Puskesmas Batulicin Tahun 2017. Batulicin, Tanah Bumbu, Kalimantan Selatan.

Sari, D. M. (2016). Hubungan sumber air minum terhadap kejadian diare pada keluarga. TRIK: Tunas-Tunas Riset Kesehatan, VI(4), 194-198. Retrieved from http://2trik.jurnalelektronik.com/index.php/ 2trik/article/view/30

Schmidt, H., Knop, C., Franke, S., Aleksic, S., Heesemann, R., \& Karch, H. 1995. Development of PCR for screening of Enteroaggregative Escherichia coli. Journal Clinical of Microbiology, 33(3), 701-705. Retrieved from https://www.ncbi.nlm.nih.gov/pubmed/775 1380

Selviana, S., Trisnawati, E., \& Munawarah, S. 2017. Faktor-faktor yang berhubungan dengan kejadian diare pada anak usia 4-6 tahun. Jurnal Vokasi Kesehatan, 3(1), 28. https://doi.org/10.30602/jvk.v3i1.78

Spano, L. C., Sadovsky, A. D. I., Segui, P. N., Saick, K. W., Kitagawa, S. M. S., Pereira, F. E. L., Fagundes-neto, U., \& Scaletsky, I. C. A. 201). Age-specific prevalence of diffusely adherent Escherichia coli in Brazilian children with acute diarrhoea. (2008), 359-363. https://doi.org/10.1099/jmm.0.47660-0

Sujaya, N., Aryantini, N. P. ., Nursini, N. ., Purnama, S. ., Dwipayanti, N. M. ., Artawan, I. ., \& Sutarga, I.. 2010. Identifikasi penyebab diare di Kabupaten Karangasem , Bali. KESMAS: National Public Health Journal, 4(4), 186-191. Retrieved from http://journal.fkm.ui.ac.id/index.php/kesma s/article/view/180

Taniuchi, M., Sobuz, S. U., Begum, S., Plattsmills, J. A., Liu, J., Yang, Z., Wang, X., Jr, W. A. P., ... Houpt, E. R. 2013. Etiology of Diarrhea in Bangladeshi Infants in the First Year of Life Analyzed Using Molecular Methods. Journal of Infection Disease, 208, 1794-1802. https://doi.org/10.1093/infdis/jit507

Taniuchi, M., Sobuz, S. U., Begum, S., PlattsMills, J. A., Liu, J., Yang, Z., Wang, X. Q., Petri, W. A., Houpt, E. R. 2013. Etiology of diarrhea in bangladeshi infants in the 
first year of life analyzed using molecular methods. Journal of Infectious Diseases, 208(11), 1794-1802. https://doi.org/10.1093/infdis/jit507

Virpari, P. K., Nayak, J. B., Thaker, H. C., \& Brahmbhatt, M. N. 2013. Isolation of pathogenic escherichia coli from stool samples of diarrhoeal patients with history of raw milk consumption. Veterinary World, 6(9), 659-663. https://doi.org/10.14202/vetworld.2013.65 9-663

World Gastroenterology Organisation. 2012. ctice guideline for acute diarrhea in adults and children: A global perspective. World Gastroenterology Organisation Global Guidelines, (February), 3-4. Retrieved from

https://journals.lww.com/jcge/fulltext/2013 /01000/Acute_Diarrhea_in_Adults_and_C hildren_A_Global.7.aspx

Zhou, Y., Zhu, X., Hou, H., Lu, Y., Yu, J., Mao, L., Mao, L., \& Sun, Z. 2018. Characteristics of diarrheagenic Escherichia coli among children under 5 years of age with acute diarrhea: A hospital based study. BMC Infectious Diseases, 18(1), 1-10. https://doi.org/10.1186/s12879-017-2936-1 